\title{
Incomplete Harmonization Contracts in International Economic Law: Report of the Panel, China - Measures Affecting the Protection and Enforcement of Intellectual Property Rights, WT/DS362/R, adopted 20 March 2009
}

\author{
KAMAL SAGGI * \\ Dedman Distinguished Collegiate Professor of Economics Southern Methodist University, Dallas, TX \\ JOEL P. TRACHTMAN** \\ Professor of International Law, The Fletcher School of Law and Diplomacy, Tufts University, Medford, MA
}

\begin{abstract}
In China-Measures Affecting the Protection and Enforcement of Intellectual Property Rights, the Panel addressed three main issues:

1. the relationship between China's censorship laws and its obligations to protect copyright under the WTO Agreement on Trade Related Intellectual Property Rights ('TRIPS');

2. China's obligations under TRIPS to ensure that its customs authorities be empowered to dispose properly of confiscated goods that infringe intellectual property rights;

3. whether China's volume and value of goods thresholds for application of criminal procedures and penalties with respect to trademark counterfeiting or copyright piracy comply with TRIPS requirements for application of criminal procedures and penalties.
\end{abstract}

International trade agreements are generally intended to cause states to internalize policy externalities. The policy externalities that arise from domestic decisions regarding intellectual property protection may deprive foreign intellectual property owners of the monopoly profits that they would otherwise derive from intellectual property protection. In connection with intellectual property protection, even a state that lacks 'traditional' market power on world markets may be able to impose terms-of-trade externalities on other states by reducing its protection of intellectual property below the global optimum. For this reason, and because of the international public-goods aspects of intellectual property, states have incentives to undersupply intellectual property protection. At least in part, TRIPS

*Email: ksaggi@smu.edu

**Email: joel.trachtman@tufts.edu 
seems to be an attempt to reduce these policy externalities. All contracts, and all international treaties, are incomplete. This case involves some good examples of treaty incompleteness. Incompleteness can arise from circumstances of uncertainty regarding the possible tradeoffs, and the optimal balance, between different goals, including state autonomy in censorship on the one hand and internalizing policy externalities in intellectual property protection on the other. We analyze the possibility that it might be efficient to allow states broad discretion over censorship. Alternatively, in connection with the requirement for criminal penalties, incompleteness can arise from uncertainty regarding the particular industry structure that might be involved, and what would constitute production of 'commercial scale' for that industry. We also question the rationale for the limitation on the use of nonviolation complaints in connection with the TRIPS, since nonviolation complaints may be used to reduce the possibility that states will use discretion, such as that granted with respect to censorship, in a manner that is inconsistent with the rationale for that discretion so as to defect from the general commitment to provide copyright or other intellectual property rights.

\section{Introduction}

In China-Measures Affecting the Protection and Enforcement of Intellectual Property Rights ('China-IP Rights'), ${ }^{1}$ which was not appealed, and therefore was adopted without an Appellate Body review, the Panel addressed three main issues:

1. the relationship between China's censorship laws and its obligations to protect copyright under the WTO Agreement on Trade Related Intellectual Property Rights ('TRIPS');

2. China's obligations under TRIPS to ensure that its customs authorities be empowered to dispose properly of confiscated goods that infringe intellectual property rights;

3. whether China's volume and value of goods thresholds for application of criminal procedures and penalties with respect to trademark counterfeiting or copyright piracy comply with TRIPS requirements for application of criminal procedures and penalties.

This case is not directly about trade in goods or services. Rather, it is about the extent to which China was required to harmonize and enforce its intellectual property law for the benefit of persons of other WTO member states. The TRIPS Agreement, which was part of the WTO single undertaking agreed in 1994, provides for a minimum level of protection of intellectual property rights and enforcement of those rights. Each of the US claims in this case involves a challenge to the implementation by China of its obligations under the TRIPS Agreement; each involves a question of interpretation of the scope of protection required under the TRIPS Agreement. However, these TRIPS claims can be understood in terms of 
concerns regarding policy externalities - harm to US firms - and more specifically regarding terms-of-trade externalities.

The establishment of certain minimum levels of IPR protection might be seen as a third level of discipline on domestic, or 'behind the border', regulation. The first level of discipline is a requirement of national treatment, as discussed in Horn. ${ }^{2}$ A second level of discipline is a proportionality requirement, as discussed and compared to national treatment in Hoekman and Trachtman. ${ }^{3} \mathrm{~A}$ third level is a requirement for harmonization of IPRs that basically resulted in a significant increase in the degree of IPR protection available in most of the developing world. These three levels do not neatly map into either magnitudes of discipline or degree of specificity of obligation. However, all three may be understood, like much international law in this area, as addressing policy externalities that may arise from actions of the regulating state. National-treatment requirements may be understood as protecting imports from differential treatment motivated by protectionist goals, and proportionality might be understood either as supplementing national treatment or as imposing an additional requirement of rationality in regulation as applied to imports. These disciplines can be understood as 'negative integration' in the sense that they prohibit certain types of national measures. On the other hand, the establishment of minimum levels of IPRs under TRIPS recognizes that each state may have an incentive to enact a level of regulation that falls below the globally efficient level. But the fact that nations have incentives to under-protect intellectual property does not necessarily imply that it is efficient to equalize the degree of IPR protection in all nations. Indeed, while such harmonization of IPRs is called for under TRIPS, Grossman and Lai ${ }^{4}$ have argued convincingly that such harmonization is neither necessary nor sufficient for achieving global efficiency. In other words, in an open global economy, while each nation will generally undersupply IPR protection and attempt to free-ride on the protection provided by other countries, efficient IPR reform does not require all nations to adopt the same set of IPR policies, since nations are heterogeneous with respect to innovative capacity, market size, and a variety of other relevant variables. Nevertheless, the strengthening of IPR protection in many developing countries that was called for under TRIPS can be viewed as a type of 'positive integration'.

To varying degrees, both negative integration and positive integration can be seen as attempts to internalize what would otherwise be policy externalities imposed by the pursuit of policies based purely on national interest. However, in the case of each of national treatment, proportionality, and harmonization there is always a degree of contractual incompleteness: it is impossible to specify

2 Henrik Horn (2006), 'National Treatment in the GATT', 96:1 The American Economic Review, 394-404.

3 Bernard Hoekman and Joel P. Trachtman (2010), 'Continued Suspense: EC-Hormones and WTO Disciplines on Discrimination and Domestic Regulation', 9:01 World Trade Review, 151-180.

4 Gene M. Grossman and Edwin L.-C. Lai (2004), 'International Protection of Intellectual Property', 94 : 5 The American Economic Review, 1635-1653. 
explicitly the treatment of every anticipated circumstance, and it is also impossible ex ante to anticipate every possible circumstance. Each of the United States's three claims in the China-IP case involves a TRIPS provision that could have been drafted more specifically, with more precision. How can we explain the existing level of incompleteness of the WTO 'contract' with respect to the establishment of minimum standards for enforcement of IPR law? What are the implications of this incompleteness?

Horn, Maggi, and Staiger (referred to as 'HMS') ${ }^{5}$ have argued that the WTO can be viewed as an incomplete contract whose form is endogenously determined. They note that the WTO agreement displays both rigidity as well as discretion: while trade instruments are largely bound (and therefore rigid), domestic instruments are largely left to the discretion of governments except that they have to abide by the principle of national treatment. Can this approach be applied to shed some light on the present case?

In Sections 1, 2, and 3, we describe the Panel's analysis in each of the three major issues addressed in this decision. In Section 4, we suggest an incomplete contracts analysis of these issues.

\section{Copyright and censorship}

As to the first issue of this case, the main question, in summary, is whether China is permitted to deny copyright protection to works that are not permitted to be published in China due to censorship. To some extent, as China argues, it is a moot point: if you lack the right to publish in China, and for reasons of censorship China also prevents others from publishing your work, why would you need copyright protection ? ${ }^{6}$

In any event, TRIPS incorporates by reference Article 17 of the Berne Convention, which provides for broad rights for governments to censor. But TRIPS also contains very specific formal obligations to accord copyright protection to works, and to enforce copyright protection, and Article 17 is not structured as an exception to these obligations but as an independent right of states. So, the Panel is called upon to reconcile within TRIPS this set of possibly inconsistent norms. One type of contractual incompleteness is incomplete reconciliation of different values within the WTO treaty.

While this case could be understood as a conflict between the permissive approach (as to state action) to censorship of Article 17 of the Berne Convention and the restrictive approach of human-rights law, the Panel did not mention the

5 Henrik Horn, Giovanni Maggi, and Robert W. Staiger (2010), 'Trade Agreements as Endogenously Incomplete Contracts', 100:1 The American Economic Review, 394-419.

6 On the other hand, perhaps copyright protection would protect authors' rights against unauthorized edited versions, or in circumstances in which the censorship is not as fully enforced as copyright would be. Copyright would often be enforced through private claims, whereas censorship is based on government enforcement. 
possible application of human-rights norms to limit the scope of censorship by states. ${ }^{7}$ Another type of contractual incompleteness is incomplete reconciliation of different values between one treaty regime and another.

The applicable WTO law - the TRIPS Agreement - incorporates by reference certain provisions of the 1971 Berne Convention on Copyright. The relevant portion of the Berne Convention, Article 5(1), protects the rights of authors 'in countries ... other than their country of origin'. Other provisions of the TRIPS Agreement and the Berne Convention set minimum standards for protection of copyright. This harmonization was intended to enhance the protection of the intellectual property rights of foreign persons, not to enhance either the protection of intellectual property rights of domestic persons, or the freedom of expression of anyone. Of course, as a collateral matter, the protection of rights of foreign authors could enhance freedom of expression for domestic persons, and it might be that harmonization for the benefit of foreign authors would naturally lead to a decision to conform national rules for the benefit of domestic authors.

\section{The facts}

This case, brought by the United States, did not involve a particular copyright that China was alleged not to have recognized or protected. Rather, it was an 'as such' case, in which the United States claimed that China's copyright law did not, as such, comply with WTO law. Since this is an 'as such' case, the only relevant 'facts' are those about what the Chinese law provides and how it is applied - there was no concrete case before the Panel to assess. ${ }^{8}$ So it was incumbent upon the Panel to make an objective assessment of the relevant Chinese law.

Article 4(1) of the Chinese Copyright Law ('CCL'), according to the agreed translation in this case, reads as follows: 'Works the publication and/or dissemination of which are prohibited by law shall not be protected by this Law.' So, the US concern was that this provision would deny copyright protection to works that, under WTO law, are required to be protected. The United States was concerned both about (i) grant of copyright status, and (ii) enforcement of copyright law to protect the copyrighted work.

While Article 4(1) of the CCL on its face seems clear, there were substantial arguments regarding its interpretation and application. China acknowledged that Article $4(1)$ of the CCL denies protection to certain works due to their content. ${ }^{9}$ The Panel found that Article 4(1) denies the protection of Article 10 of the CCL to

\footnotetext{
7 See Tomer Broude (2009), 'It's Easily Done: The China-Intellectual Property Rights Enforcement Dispute and the Freedom of Expression', Hebrew University International Law Forum Research Paper No. 22-09, October.

8 The Panel referred to the statement by the Appellate Body in US - Corrosion-Resistant Steel Sunset Review (WT/DS244/AB/R, adopted 9 January 2004) to the effect that "When a measure is challenged "as such", the starting point for an analysis must be the measure on its face. If the meaning and content of the measure are clear on its face, then the consistency of the measure as such can be assessed on that basis alone' (para. 168).

9 Panel Report, para. 7.30 .
} 
certain works. ${ }^{\mathbf{1 0}}$ Article 10 of the CCL sets forth the four moral rights and 13 economic rights of copyright holders. Relying on a letter authored by the Chinese Supreme People's Court in connection with the so-called 'Inside Story' case, the Panel found that Article 4 of the CCL denies copyright protection when the publication or dissemination of a work is prohibited due to its content. ${ }^{11}$ However, China argued that only works affirmatively found to be illegal are unprotected. ${ }^{12}$ China argued that denial of copyright protection under Article 4(1) requires determination by a court or the National Copyright Administration of China ('NCAC') during enforcement proceedings. ${ }^{13}$

China's first written submission argued that 'illegal' referred to works that are 'completely unconstitutional or immoral'. ${ }^{14}$ The NCAC, in a letter to the Supreme People's Court in connection with the Inside Story case, had stated that the 'works the publication and dissemination of which are prohibited by law' in Article 4 of the CCL 'refer only to works whose contents are illegal (reactionary, pornographic, or superstitious contents)'. However, China's content review regulations list a number of additional categories of works that are censored, including those that incite hatred, propagate cults, disrupt public order and undermine social stability, propagate obscenity, gambling, or violence, insult or slander others, or infringe upon legitimate rights and interests of others, jeopardize social ethics, and other contents banned by laws. ${ }^{15}$ The Panel understood that the NCAC statement referring to 'reactionary, pornographic, or superstitious contents' was a summary reference to this broader list. ${ }^{16}$

The Panel found that works denied protection are those that have already failed content review, and deleted portions of works edited to satisfy content review. ${ }^{\mathbf{1 7}}$ It determined that the United States had not made a prima facie case with respect to works never submitted, works awaiting results, and unedited versions of works for which an edited version had been approved.

\section{Legal analysis}

The dispute in this case was about the relationship between (i) the obligation to protect the intellectual property rights of foreign authors, on the one hand, and (ii) the scope of discretion of the obligor state to censor that work, on the other hand. The United States claimed that the discretion of the state to censor could not limit the obligation to protect intellectual property rights of foreign authors. China argued first factually that the relevant Chinese law did not restrict the protection of

10 Ibid., para. 7.50 .

11 Ibid., para. 7.52 .

12 Ibid., para. 7.55 .

13 Ibid., paras. 7.64, 7.66.

14 Ibid., para. 7.78, quoting China's first written submission.

15 Ibid., para. 7.79 .

16 Ibid., para. 7.81 .

17 Ibid., para. 7.103 . 
these rights, and second that the right to censor either fully satisfied the obligation to protect these rights, or made it moot.

From a broadly theoretical perspective, this dispute demonstrates the difficulty of limiting any legal rule to its intended purpose, and the impossibility of specifying a particular category of obligation so as to isolate its effects from other areas of law or policy. It also shows the difficulty of anticipating and addressing these types of extensions or collisions. International lawyers refer to this problem as the problem of fragmentation, but it can be understood within a broader set of problems categorized by economists as the problem of incomplete contracts. ${ }^{18}$

The United States claimed that under the CCL, authors of unauthorized works do not enjoy minimum rights granted by the Berne Convention, inconsistently with Article 5(1) of the Berne Convention, which is incorporated by reference in the TRIPS via Article 9.1 of TRIPS. Article 5(1) provides as follows:

Authors shall enjoy, in respect of works for which they are protected under this Convention, in countries of the Union other than the country of origin, the rights which their respective laws do now or may hereafter grant to their nationals, as well as the rights specially granted by this Convention.

The US claim was predicated on the last clause of this provision - the United States argued that the CCL denies 'rights specially granted by [the Berne] Convention'. The Panel found that China's law violated Article 5(1) of the Berne Convention, as incorporated pursuant to Article 9.1 of TRIPS, as to works that have already failed content review, and also as to deleted portions of works edited to satisfy content review. ${ }^{19}$

China offered a defense based on Art. 17 of the Berne Convention, which also is incorporated in TRIPS via Article 9.1 thereof, and provides as follows:

The provisions of this Convention cannot in any way affect the right of the Government of each country of the Union to permit, to control, or to prohibit, by legislation or regulation, the circulation, presentation, or exhibition of any work or production in regard to which the competent authority may find it necessary to exercise that right.

China understood this provision as broadly ensuring the sovereignty of the state to censor. China claimed that this broad language 'effectively denies WTO jurisdiction in this area' ${ }^{20}$ Indeed, the reference to the determination of the competent authority may be understood as providing a 'self-judging' right to censor, similar to the portion of Article XXI(b) of GATT that has been understood to be 'selfjudging' as to the necessity of security measures. The Panel agreed that Article 17

18 For an effort to do so, see Joel P. Trachtman (1999), 'The Domain of WTO Dispute Resolution', 40 Harvard International Law Journal, 333.

19 Panel Report, para. 7.117.

20 Ibid., para. 7.120, quoting China’s rebuttal submission, paras. 286-287. 
of the Berne Convention allows censorship for public-order purposes. ${ }^{21}$ Note that, within an incomplete contracts framework, China may be viewed as arguing either that (i) the contract authorizes the obligor state itself to determine the level of protection, or (ii) that there is no effective obligation in this context.

However, while there is broad authority for censorship, this authority does not, according to the Panel, extend to denying copyright protections. The right reserved for states under Article 17 to control 'circulation, presentation, or exhibition' does not include a number of rights granted to copyright holders by the Berne Convention. ${ }^{22}$ Furthermore, according to the Panel, censorship may allow governments to interfere with the exercise of copyright rights, but not with the existence of these rights. ${ }^{23}$ This distinction may have limited practical effect.

Indeed, China argued that copyright protection is a 'legal and material nullity' because economic rights are preempted by censorship. ${ }^{24}$ In response, the Panel referred to the fact that Article 3.8 of the WTO Dispute Settlement Understanding provides for prima facie nullification or impairment, and that therefore there is no need to show actual economic effects. ${ }^{25}$ China argued that public censorship renders private enforcement unnecessary. Again, the problem with this argument is that there is more to copyright than the right to publish. The Panel found assertions by China that it enforces censorship against copyright violations in respect of censored works unsubstantiated. It is procedurally interesting, and perhaps questionable that, in an 'as such' case, where there is no actual instance of application of the allegedly illegal national measure, the defending state is required to show actual instances of measures that would obviate the alleged illegality.

The United States made an additional claim that China also violated its obligations to provide enforcement mechanisms for copyright under Article 41.1 of TRIPS. In response, China argued that its censorial ban on publication is a form of 'effective action' - an 'alternative form of enforcement against infringement'. The Panel rejected this argument, finding that Part III of TRIPS requires a broader minimum set of enforcement procedures. ${ }^{26}$ This finding is important as it suggests that the existence of alternative forms of protection against violation of IPRs - such as that provided for by the use of censorship - does not mean that a country need not set up the enforcement procedures called for under TRIPS. Thus, the Panel concluded that 'the Copyright Law, specifically the first sentence of Article 4, is inconsistent with China's obligations under Article 41.1 of the TRIPS Agreement'. ${ }^{27}$

21 Ibid., para. 7.126.

22 Ibid., para. 7.127.

23 Ibid., para. 7.132.

24 Ibid., para. 7.134.

25 Ibid., para. 7.138 .

26 Ibid., para. 7.180.

27 Ibid., paras. 7.179-7.181. 


\section{Disposal of infringing goods}

The United States claimed that certain Chinese measures relating to customs procedures on the import or export of infringing goods violated TRIPS Articles 46 and 59. Article 59, addressing 'special requirements relating to border measures', provides that 'competent authorities shall have the authority to order the destruction or disposal of infringing goods in accordance with the principles set out in Article 46'.

The Panel found that Article 59, included in Section 4 of TRIPS, only addresses infringing imports, and not exports. ${ }^{28}$ While the US claim referred generally to infringing goods, the United States took no position with respect to the question of whether the first sentence of Article 59 also applies to exports, and the Panel found that it did not. The Panel examined Article 51 of TRIPS, as context for Article 59. Article 51 provides states with an option to provide similar procedures to those contained in Section 4 with respect to exports, suggesting that the required procedures do not otherwise apply to exports.

Article 46 provides in relevant part as follows:

In order to create an effective deterrent to infringement, the judicial authorities shall have the authority to order that goods that they have found to be infringing be, without compensation of any sort, disposed of outside the channels of commerce in such a manner as to avoid any harm caused to the right holder, or, unless this would be contrary to existing constitutional requirements, destroyed.

The United States claimed that the relevant authorities lacked the requisite authority to order the destruction or disposal of infringing goods in accordance with the principles set out in Article 46.

The Chinese regulations at issue provided as follows:

Where the confiscated goods which infringe on intellectual property rights can be used for the social public welfare undertakings, Customs shall hand such goods over to relevant public welfare bodies for the use in social public welfare undertakings. Where the holder of the intellectual property rights intends to buy them, Customs can assign them to the holder of the intellectual property rights with compensation. Where the confiscated goods infringing on intellectual property rights cannot be used for social public welfare undertakings and the holder of the intellectual property rights has no intention to buy them, Customs can, after eradicating the infringing features, auction them off according to law. Where the infringing features are impossible to eradicate, Customs shall destroy the goods.

The United States criticized these regulations as follows:

Donation to social welfare bodies can be harmful to a right holder and nothing appears to prevent such bodies from selling the infringing goods; sale to the right holder harms the right holder in the amount that the right holder pays for the

28 Ibid., para. 7.231. 
infringing goods; and auction does not constitute disposal outside the channels of commerce and, absent his consent, may harm the right holder. Where any of these three options is available, the authorities are not authorized to order destruction of the infringing goods. ${ }^{29}$

The United States argued that the measures at issue created a 'compulsory scheme' limiting the authority of customs officials to destroy infringing goods, and requiring them to give priority to disposal options that allow the infringing goods to enter commerce or otherwise harm the right holder. The focus of the argument, therefore, was on the extent to which China was entitled to condition or prioritize the action of its authorities. In simple terms, where Article 46 says that the 'competent authorities shall have the authority' to take specified actions, (i) are the competent authorities required to take those actions, and (ii) can any conditions be imposed on the ability of the competent authorities to take those actions?

Facts

This also was a challenge of the Chinese measures 'as such', and therefore no specific case of application of these measures was pleaded by the United States.

However, interestingly, the Panel found that during the period 2005-2007, 'all confiscated infringing imports were either donated to the Red Cross Society of China $(0.12 \%)$ or destroyed $(0.02 \%)$. The volume of infringing imports that was sold to the right holder, or auctioned, was zero. ${ }^{30}$ The percentages in parentheses are calculated against a base of all goods disposed of or destroyed under China's measures at issue; $99.85 \%$ of infringing goods disposed of or destroyed were destined for exportation. ${ }^{31}$ Recall that the Panel found that the first sentence of Article 59 of TRIPS only applies to imports, not exports.

\section{Legal analysis}

The Panel found that the terms of Article 59 do not indicate that the authority to order the specified types of remedies must be exclusive. ${ }^{32}$ The list of remedies is not exhaustive. ${ }^{33}$ National authorities are required to be granted certain authority, but are permitted to be accorded the discretion to make other dispositions. Nor does the requirement for the grant of authority imply a requirement that such authority be exercised. ${ }^{34}$ Nor does the requirement for the grant of authority imply that conditions cannot be set for the exercise of that authority. ${ }^{35}$ Furthermore, the Panel found that the requirement in Article 46 that authority to order a remedy be

29 Ibid., para. 7.197 (emphasis in original).

30 Ibid., para. 7.232 .

31 Ibid., para. 7.228 .

32 Ibid., para. 7.240 .

33 Ibid., para. 7.239 .

34 Ibid., para. 7.236 .

35 Ibid., para. 7.246. 
exercised 'in such a manner as to avoid any harm caused to the right holder' is applicable only to the remedy of disposal outside the channels of commerce. ${ }^{36}$

However, the United States argued that by establishing a mandatory sequence of possible remedies, the Chinese measure denied Chinese authorities the required authority. The Panel agreed that if a different method of disposition is mandatory, then this may preclude authority that is required by Article 59. ${ }^{37}$

As noted above, the Chinese measure provided for three disposal methods besides destruction: (i) donation to social-welfare bodies, (ii) sale to the right holder, and (iii) auction.

As to donation to social-welfare bodies, the United States claimed that this method of disposal might cause harm to rights holders, including by virtue of subsequent sale by the social-welfare bodies. The Panel found that if the socialwelfare bodies sell the infringing goods into ordinary commerce, this would not constitute disposal outside the channels of commerce. ${ }^{38}$

The United States argued that the Chinese measures failed to provide discretion to the Chinese customs authorities to determine that transfer to a social-welfare body might harm the right holder, and therefore failed to comply with the principles of Article 46, as required by Article 59 of TRIPS. Interestingly, in this 'as such' case, the Panel relied on the fact that 'nothing in the evidence suggests that any harm has ever been caused, or is likely to be caused, to right holders' reputations due to donation of infringing goods under the measures at issue'. ${ }^{39}$ Therefore, the Panel found that the United States failed to demonstrate that the Chinese customs officials lacked the requisite authority to dispose of the goods in such a manner as to avoid harm to the right holder.

As to the risk of sale by social-welfare bodies, China pointed out that the implementing measures for the Chinese regulations provide that the customs authorities shall 'carry out necessary supervision'. ${ }^{40}$ The Panel found that the United States failed to show that customs authorities lacked the requisite authority in this context to ensure that the right holder is not harmed. ${ }^{41}$

As to sale to the right holder, the Panel found that, since there are always other options available, and sale to the right holder only takes place with the consent of the right holder, 'there appear to be no circumstances in which sale to the right holder is the only option available and could preclude any authority required by Article 59, ${ }^{42}$

As to the authority of Chinese customs authorities to auction infringing goods, the Panel observed that this is not a method of disposal that is required to be

36 Ibid., para. 7.244.

37 Ibid., para. 7.252.

38 Ibid., para. 7.279.

39 Ibid., para. 7.297.

40 Ibid., para. 7.299.

41 Ibid., para. 7.324.

42 Ibid., para. 7.326. 
authorized under Article 59, but recalled its findings that the remedies specified in Article 59 are not required to be exclusive. Therefore, the authorization for auction is not itself inconsistent with Article 59. ${ }^{43}$ The United States argued that the Chinese measures treated auction as a 'compulsory prerequisite' to destruction, thereby precluding authority for destruction, in violation of Article 59. However, the Panel found that the Chinese measures only provided authority for auction, rather than a requirement. ${ }^{44}$

Finally, the Panel found that in regard to counterfeit trademark goods, China's measures allow that the 'simple removal' of the trademark unlawfully affixed is sufficient to permit release of the goods into commerce in more than just exceptional cases, and therefore violates the principle stated in the last sentence of Article 46.

\section{Thresholds for criminal procedures and penalties}

The United States also argued that China had failed to provide appropriate criminal penalties for certain trademark and copyright infringement, as required by the first sentence of Article 61 of TRIPS, which provides as follows: 'Members shall provide for criminal procedures and penalties to be applied at least in cases of wilful trademark counterfeiting or copyright piracy on a commercial scale.' This was another claim regarding the quality of China's implementation of its TRIPS obligations, in which the United States argued that the Chinese thresholds for criminal penalties were higher than those permitted by Article 61 .

At stake again was the degree of discretion retained by member states of the WTO under the TRIPS. China argued that the ostensible principle of in dubio mitius applies to protect the discretion of member states in the special field of criminal law. ${ }^{45}$ The Panel noted that its interpretative mandate is set by Article 3.2 of the WTO Dispute Settlement Understanding. While recognizing 'the sensitive nature of criminal matters and attendant concerns regarding sovereignty', the Panel stated that 'these concerns may be expected to find reflection in the text and scope of treaty obligations regarding such matters as negotiated by States and other Members'. ${ }^{46}$ This seems to be an implicit rejection of the argument for special deference, suggesting that to the extent that member states determine that deference is appropriate, they would express the requirement for deference in the specific terms of the treaty text.

China further argued that Article 61 is too general to create legally enforceable obligations, ${ }^{47}$ and further asserted that it retains unfettered discretion under Article 1.1 of TRIPS, which provides that 'Members shall be free to determine the

43 Ibid., para. 7.327.

44 Ibid., para. 7.343 .

45 Ibid., para. 7.497.

46 Ibid., para. 7.501 (citation omitted).

47 Ibid., paras. 7.508-7.513. 
appropriate method of implementing the provisions of this Agreement within their own legal system and practice.' The Panel rejected this argument.

Facts

Here again, the United States challenged China's measures 'as such'. Thus, in order for China to be in breach of the first sentence of Article 61, in this 'as such' case, the United States would be required to show that there is a class of cases of counterfeiting or piracy that are (i) willful, and (ii) of a commercial scale, for which China does not provide criminal penalties. The United States was unable to bear this burden. In particular, the United States offered much evidence in the form of newspaper articles, and the Panel found this evidence to lack sufficient credibility. ${ }^{48}$

The basis for this US complaint was China's Criminal Law, Judicial Interpretation No. 19, and Judicial Interpretation No. 16 - measures that established specific thresholds that had to be met in order for criminal punishments to be imposed. For example, under Judicial Interpretation No. 19, forging of registered trademarks can result in criminal punishments only when the number of forged units is not less than 20,000 pieces or if the 'illegal business operation volume' is not less than 50,000 Yuan, or if the amount of illegal gains is less than 30,000 Yuan.

\section{Legal analysis}

The first interpretative question for the Panel involved the determination of the meaning of 'commercial scale' in the first sentence of Article 61. The United States argued that the Chinese thresholds were quantitatively too low, and that, qualitatively, they failed to take into account certain necessary factors. However, the United States accepted that, in principle, numerical thresholds could be acceptable without more. ${ }^{49}$

The essence of the US complaint here was that the use of such thresholds necessarily implied that any act of trademark counterfeiting or copyright piracy that fell below these thresholds was free from the risk of criminal prosecution. The Panel noted that the US complaint with respect to Article 61 had 'two limbs'. The first limb concerned the level and the method of calculating thresholds wherein the threshold levels were argued to eliminate whole classes of criminal activities from risk of prosecution. The second aspect of the complaint was that the use of specific numerical thresholds basically required law-enforcement officials to 'disregard other indicia of counterfeiting and piracy', such as the presence of unfinished products and fake packaging.

The first limb of the US complaint received careful scrutiny from the Panel, whereas the second limb was dismissed summarily on the grounds that the 
United States had not made a prima facie case with respect to other indicia of infringement.

It is worth noting that, in and of itself, the use of thresholds by China can hardly be problematic. After all, enforcement costs for criminal prosecution are nontrivial and, either implicitly or explicitly, thresholds are bound to guide enforcement efforts. Indeed, efficiency requires turning a blind eye to trivial occurrences of counterfeiting and piracy. For example, few would argue that photocopying of a few pages (but exceeding an amount considered 'fair use') from a copyrighted textbook for personal use by a student should be subject to criminal prosecution. But, on the other hand, if a student undertook such illegal copying on a large enough scale for selling them to classmates, the question becomes more serious. The use of a threshold as guiding principle cannot be avoided: only if the level of copyright piracy exceeds a certain amount would criminal prosecution appear to make legal and economic sense. Indeed, as the Panel Report notes, the United States conceded as much since it did not object to the use of thresholds per se, although it did argue that the fact that China uses thresholds across a range of commercial crimes ought to have no bearing on the Panel's 'assessment of whether China meets its international obligations under the first sentence of Article 61' of TRIPS. ${ }^{50}$

The first limb of the US complaint brought the concept of 'commercial scale' to the forefront, and the Panel Report devoted much space to it. Indeed, from an economic viewpoint, this is a reasonably important aspect of this case and is therefore worth discussing in some detail.

The Panel noted that TRIPS Article 61(1) creates an obligation to provide for criminal procedures for all willful acts of counterfeiting and piracy on a commercial scale. In other words, only those acts of piracy and counterfeiting that occur on a 'commercial scale' must be subject to criminal prosecution. Indeed, the Panel clarified the scope of the obligation created by Article 61(1) by noting that it is subject to four different limitations, an emphasis that is likely to prove important for future TRIPS related disputes at the WTO. First, the Panel noted that:

the obligation applies to trademarks and copyright rather than to all intellectual property rights covered by the TRIPS Agreement. The fourth sentence of Article 61 gives Members the option to criminalize other infringements of intellectual property rights, in particular where they are committed wilfully and on a

50 See Gene M. Grossman and Petros C. Mavroidis (2003), 'United States - Section 110(5) of the US Copyright Act, Recourse to Arbitration under Article 25 of the DSU: Would've or Should've? Impaired Benefits Due to Copyright Infringement', 2:2 World Trade Review, 233-249. Grossman and Mavroidis note that the optimal enforcement policy is not one that ensures $100 \%$ compliance (i.e., zero copyright violations in our context) since the costs of enforcing such perfect compliance would far outweigh the benefits. In other words, below some level of thresholds, it would be globally optimal to let IPR violations occur. 
commercial scale. Despite the potential gravity of such infringements, Article 61 creates no obligation to criminalize them. ${ }^{51}$

The fact that the obligation applies only to trademarks and copyrights means that there exists a wedge between the degree of protection available under TRIPS to different types of IPRs, with somewhat stronger protection afforded to copyrights and trademarks relative to other IPRs, such as patents. This obviously raises the question of why this might be so. One potential answer is that, with the exception of pharmaceuticals, violations of patents in the form of illegal imitation of products and technologies are relatively costlier to commit than violations of copyrights and trademarks. If so, the legal deterrent required in order to provide equivalent protection to copyrights and trademarks might be greater.

The second limitation of Article 61 noted by the Panel was that the obligation to provide for criminal procedures 'applies to counterfeiting and piracy rather than to all infringements of trademarks and copyright' ${ }^{52}$ Indeed, the Panel went so far as to note that 'the records of the negotiation of the TRIPS Agreement confirm that the term "infringements of trademarks and copyright" on a commercial scale was considered in the draft provision on criminal procedures but ultimately rejected'. In other words, the negotiators found it useful to single out counterfeiting and piracy as serious enough violations worthy of criminal prosecution, although the terms 'counterfeiting' and 'piracy' are not themselves defined under TRIPS.

The third limitation of the obligation singled out by the Panel was that the use of the word 'willful' implies that infringement ought to have been 'intentional' so that there was no obligation 'to make such penalties available with respect to acts of infringement committed without the requisite intent'. In the Panel's view, this focus on intent reflected the criminal nature of enforcement procedures under consideration.

The fourth limitation, and easily the most important one from an economic perspective, is indicated by the use of the words 'commercial scale'. Indeed, the Panel noted that

The principal interpretative point in dispute is the meaning of the phrase 'on a commercial scale'. This phrase functions in context as a qualifier, indicating that wilful trademark counterfeiting or copyright piracy is included in the scope of the obligation provided that it also satisfies the condition of being 'on a commercial scale'. Accordingly, certain acts of wilful trademark counterfeiting or copyright piracy are excluded from the scope of the first sentence of Article $61 .^{53}$

After an extensive review of dictionary definitions, and other uses of the terms in the WTO treaties and in other related contexts, the Panel found that " "commercial scale" is the magnitude or extent of typical or usual commercial activity'.

51 Panel Report, para. 7.518 (emphasis added).

52 Ibid., para. 7.519.

53 Ibid., para. 7.525 (emphasis added). 
"Therefore, counterfeiting or piracy "on a commercial scale" refers to counterfeiting or piracy carried on at the magnitude or extent of typical or usual commercial activity with respect to a given product in a given market. ${ }^{54}$

The Panel emphasized that while 'commercial' is a qualitative concept, 'scale' is a quantitative one, noting that it referred to the size of counterfeiting and piracy. The Panel's position was quite different from that of the United States, which initially insisted that any infringer pursuing financial gain in the market was acting on a commercial scale. The Panel also did not agree to the Chinese position that commercial scale was equivalent to 'industrial scale activity'. Instead, the Panel noted that what constitutes commercial scale depends upon the product or market in question. This necessarily implies that the Chinese thresholds for criminal prosecution could indeed be too high for certain markets, but the Panel noted that the United States had not provided any hard evidence demonstrating this was the case for any specific market or product in China.

Indeed, the evidence provided by the United States was rather thin in that it was comprised of a few newspaper and magazine articles. Furthermore, the Panel correctly rejected the use of GDP per capita as a measure of commercial scale, since it is too broad a measure that may or may not be relevant for any specific market. Characterizing the evidence submitted by the United States as anecdotal in nature, the Panel ruled that the United States had failed to establish that China's criminal thresholds were inconsistent with its obligations under TRIPS Article 61(1).

While it is easy to fault the United States for not providing sufficient evidence in support of its position that Chinese thresholds were allowing counterfeiting and piracy to occur on a commercial scale in certain markets, it is worth bearing in mind that violations of 'behind the border' rules and commitments are not easy to prove. The collection of such evidence would require the cooperation of Chinese officials responsible for enforcing the law. If such officials enforce TRIPS fully, there would be little evidence to collect. However, if they do not, they certainly have no incentive to cooperate with the United States and provide incriminating evidence against themselves! Indeed, this basic dilemma might partly explain why the United States submitted so little hard evidence in support of its position, choosing to rely more on explicit statements contained in Chinese laws as opposed to the lack of 'enforcement' of those laws.

A potential interpretation of the Panel's definition of 'commercial scale' is that it is a general 'standard', compliance with which is to be determined by disputesettlement bodies on a case-by-case basis. This standard may be understood as a kind of delegation to Panels to evaluate facts to determine whether they meet the standard's requirements. The Panel noted that, 'what constitutes a commercial scale for counterfeiting or piracy of a particular product in a particular market will

54 Ibid., para. 7.577. 
depend on the magnitude or extent that is typical or usual with respect to such a product in such a market, which may be small or large' ${ }^{55}$ In this way, the use of a standard may be seen as a special type of contractual incompleteness, with a special type of institutional mechanism to provide for ex post completion. Thus, the Panel noted that the determination of 'commercial scale' cannot be rigidly fixed ex ante.

Given that commercial scale is context specific, whether a certain level of illegal copying is deemed to occur on a commercial scale or not is a judgment regarding an appropriate standard that can be made only with the requisite market data in hand for a given work. Thus, the TRIPS contract is incomplete in that it does not include a specific definition of 'commercial scale'. With the Panel's decision, it can be argued that commercial scale is a context-specific standard that is to be determined by future WTO Panels on a case-by-case basis. What this implies, of course, is that the explicit numerical thresholds specified in Chinese law cannot, in and of themselves, be considered too high or too low. Indeed, as we have argued above, even from an efficiency perspective, the existence and use of such thresholds are not inherently problematic.

\section{Economic and policy analysis}

China has always guarded its sovereignty vigorously. With respect to the claims in the present case regarding copyright protection for prohibited works, and with respect to the claims regarding criminal penalties, China made explicit arguments that the sovereign right to censor, and to determine its own criminal laws, dominates review under WTO law. With respect to the claims regarding disposal of infringing goods, the core argument was also about retained autonomy after harmonization under TRIPS, and in particular the retained discretion to exercise authority that is required to be made available to national authorities under TRIPS. The TRIPS agreement can be characterized in these three contexts as incomplete in its specification of the relationship between the relevant harmonization obligations, and certain areas of retained national autonomy.

\section{Policy externalities in connection with intellectual property rights}

Of course, all international law restricts the autonomy of states, and all international trade law may be understood in terms of management of policy

55 The Panel is quite sensible to say that thresholds have to be specific to the context. So in this sense, the Chinese law's specification of rigid thresholds might be a bit odd: infringing sales of 50,000 Yuan might be astronomical (and therefore on a commercial scale) in one market while trivial in another. Furthermore, it is worth noting that the sales revenue lost by the IPR holder and the sales revenue gained by an infringer need not always correlate perfectly. Only when the sales revenue of infringers exceeds that which the IPR holder would have earned if infringement were absent does the use of thresholds based on infringing sales work in favor of the rights holder. 
externalities. The TRIPS is no exception. As pointed out by Grossman and Mavroidis:

In a non-cooperative world regime of intellectual property protection, externalities might come in two main forms. First, governments may have a national incentive to discriminate against the intellectual property rights of foreign citizens. This explains the requirements for national treatment that are included in TRIPs, and in the Berne Convention and Paris Treaty before it. Second, even with national treatment, national governments may choose to provide insufficient protection for intellectual property relative to the strength of protection that would be globally efficient. ${ }^{56}$

The basic calculus of optimal patent protection in a closed economy has been well understood since Nordhaus, who argued that the optimal policy must balance the marginal benefit of inducing more innovation against the marginal static loss imposed by extending monopoly power. ${ }^{57}$ More recently, Grossman and $\mathrm{Lai}^{58}$ have provided a thorough analysis of optimal patent policies in a two-region (North-South) open-economy context. It turns out that the presence of international trade matters a great deal. More specifically, they highlight two reasons why patent protection will be too weak in an open-economy setting when countries choose policies to maximize their own welfare. As was also noted by Grossman and Mavroidis, these two reasons are as follows:

First, national governments do not take into account in their cost-benefit calculus the benefits that accrue to foreign citizens when protection induces additional investments in intellectual property. Second, national governments do not consider as an offset to the static cost of granting patent and copyright protection the monopoly profits that accrue to foreign rights holders. For both these reasons, a global regime of independently chosen patent and copyright policies will provide too little incentive for investment in intellectual property relative to the aggregate reward that would maximize world welfare. In effect, countries have an incentive to free ride on the intellectual property rights protection provided by their trading partners. ${ }^{59}$

This is a public-goods problem. Importantly in the present case, it may be that states differ in the extent to which their citizens are benefited by either investment in intellectual property or monopoly profits of rights holders. Importantly also, the magnitudes of (i) the benefits to foreign citizens from investment induced by protection, and (ii) the monopoly profits that accrue to foreign rights holders, are uncertain.

56 See Gene M. Grossman and Petros C. Mavroidis (2003), 'United States - Section 110(5) of the US Copyright Act, Recourse to Arbitration under Article 25 of the DSU: Would've or Should've? Impaired Benefits Due to Copyright Infringement', $2: 2$ World Trade Review, 233-249 (citations omitted).

57 William D. Nordhaus (1969), Invention, Growth, and Welfare: A Theoretical Treatment of Technological Change, Cambridge, MA: MIT Press.

58 Grossman and Lai, 'International Protection of Intellectual Property'.

59 Grossman and Mavroidis, 'United States - Section 110(5) of the US Copyright Act'. 
To some extent, intellectual property protection below the globally efficient level would impose its policy externality in a way similar to a tariff, although the market mechanism can be rather different. By their very nature, IPRs bestow market power on rights holders. Therefore, any meaningful discussion of the effects of IPR enforcement (or the lack of it) has to recognize the market power of rights holders. This is important because all countries have the ability to affect the degree to which rights holders can exercise their market power locally by controlling the degree of IPR protection available in their respective markets. In other words, the presence of intellectual property-based market power makes the standard distinction between 'small' and 'large' countries somewhat superfluous.

For example, when faced with an import tariff in a foreign market, a monopolist will typically find it optimal to absorb some of the tariff and not pass it on entirely to foreign consumers. While a tariff directly affects the effective price collected by a monopolist or a right holder, the lack of IPR protection can lower the market price for the right holder's good by creating competition in the local market. Sometimes such competition can occur in the form of a lower-quality version of the original good, while at other times the copied version (such as in software or books) might work just as effectively as the original. Regardless, the competition created by the infringing product necessarily implies a reduction in the price of imports, allowing domestic infringers to profit at the expense of foreign intellectual property owners. Indeed, the competition created by the failure to protect IPRs benefits local consumers in the short run and is one reason many analyses of IPR protection in a global economy find that allowing for some level of imitative activities can be in the interest of countries that do not possess significant innovative capacity themselves. ${ }^{\mathbf{6 0}}$

Furthermore, for a state like China in which the government continues to own a significant portion of the means of production, the benefits to domestic infringers would in part be captured by the government. Of the two reasons identified by Grossman and $\mathrm{Lai}^{61}$ as to why IPR protection will generally be too weak, perhaps the second reason is more applicable in the present context since US consumption of Chinese goods that require IPR protection is not nearly as large as the Chinese consumption of US goods that require such protection. The harm inflicted by its weaker IPR protection on US producers would not be internalized by China through narrow reciprocity, resulting in a level of protection that is too low from a global-welfare perspective.

\section{TRIPS as an incomplete contract}

TRIPS requires a certain degree of harmonization of intellectual property rights across member countries of the WTO. It sets minimum standards for various types of IPRs, but, as demonstrated in the case at hand, provides a rather incomplete

60 Elhanan Helpman (1993), 'Innovation, Imitation, and Intellectual Property Rights', 61:6 Econometrica, 1247-1280.

61 Grossman and Lai, 'International Protection of Intellectual Property'. 
specification $^{62}$ of its requirements. TRIPS is internally incomplete, but it is also incomplete in an external sense: the relationship between TRIPS and other (incomplete) law - such as on the one hand the human right of expression, ${ }^{63}$ and on the other hand the sovereign right to restrict expression - is incompletely specified. In the present case, there is a moderate degree of consistency between the relevant WTO law and human-rights law, ${ }^{64}$ but the relevant WTO law was argued by China to be inconsistent with China's sovereign right to restrict expression. Thus, it might be that the incompleteness of TRIPS allows TRIPS rights to be obviated, or nullified or impaired, by a broad national discretion to censor. Furthermore, this is an asymmetric discretion, (i) since the United States censors less than China does, and (ii) to the extent that the United States has more intellectual property to protect than China does.

HMS examine the GATT, finding that it includes an interesting combination of ' rigidity, in the sense that contractual obligations are largely insensitive to changes in economic (and political) conditions, and discretion, in the sense that governments have substantial leeway in the setting of many policies. They observe that "there is a wide array of policy instruments - border measures and especially "domestic" measures - that should be constrained to keep in check each government's incentives to act opportunistically' ${ }^{65}$

HMS argue that national discretion is likely to be increased where domestic instruments are less available to manipulate the terms of trade, or where the importing country has less market power in connection with the imported good. Under these circumstances, we would expect less use of domestic measures to manipulate the terms of trade.

Intellectual property protection is one type of 'domestic' measure. Interestingly, intellectual property rights protection is different from normal trade measures, insofar as any state, even a state without conventional market power, can impose terms-of-trade externalities on exporters from other states by declining to protect their intellectual property rights. As noted above, this is because IPRs create market power that gives individual sellers the ability to influence prices, and this ability can be manipulated by importing countries by altering the product market

62 Incompleteness is a concept of limited analytical power, insofar as, in effect, all contracts are completed by default by letting the costs remain where they fall except to the extent that the contract shifts them. The more appropriate concept to refer to is actually specificity: contracts, and treaties, can be expected to vary in their specificity. States may be expected to establish treaties of varying specificity depending on the costs and benefits of specification. One alternative to specificity is implicit delegation to dispute settlement of decisionmaking authority. This institutional alternative can provide ex post contract completion, or specification. Considering the role of precedent, it can also, over time, provide greater $e x$ ante specification.

63 See, e.g., Article 19 of the International Covenant on Civil and Political Rights, Article 10 of the European Convention on Human Rights, Article 13 of the American Convention on Human Rights, and Article 9 of the African Charter on Human and Peoples' Rights.

64 See Broude, 'It's Easily Done'.

65 Horn, Maggi, and Staiger (2010), ‘Trade Agreements as Endogenously Incomplete Contracts', 394. 
conditions faced by such sellers in their markets. This fact seems to accentuate the observation of HMS to the effect that, with rising volumes of trade, and consequent increasing costs of allowing discretion, there is an increasing need to constrain domestic policies. ${ }^{66}$

This accentuation would seem to be especially likely in the case of China, which generally has world-class manufacturing capabilities, allowing it to compete with imported intellectual property-based goods. A state without local manufacturing capabilities would not be able to impose terms-of-trade externalities on exporters from other states since it would lack the means of changing market conditions faced by rights holders. In other words, if local providers are incapable of producing competing goods that violate copyrights or trademarks, the lack of local IPR enforcement would not create any competition for rights holders and therefore would not affect their prices. The criminal penalties 'commercial scale' threshold in the present case may be understood as an example of a state contingency related to the question of sufficient manufacturing capabilities - or at least sufficient manufacturing.

Under significant uncertainty as to the future state of affairs, states would wish to establish complex state-contingent contracts. As noted above, the magnitudes of (i) the benefits to foreign citizens from investment induced by protection, and (ii) the monopoly profits that accrue to foreign rights holders, are uncertain. However, contracting is costly, limiting the ability to specify state-contingencies. On the other hand, by specifying general 'standards', and delegating to disputesettlement bodies the responsibility to apply these standards, states are able to include complex state-contingency in their contracts, with significantly less variable contracting costs. This is a design feature that is not addressed in HMS, but it was clearly at work in the present case. ${ }^{67}$

Consider a simplified version of the HMS model. Suppose an import creates a local externality (like the consumption externality of HMS) that serves to directly lower the government's objective function. In connection with the first claim in this case, that relevant externality could arise because (the government believes) the consumption of the import - such as a novel or an artistic work critical of centralized power - reduces its ability to govern effectively by fomenting dissent or forces it to allocate resources away from other pursuits toward maintaining 'law and order'. Further, assume that the extent of the externality imposed by the import is uncertain and the transactions costs of contracting over censorship are quite large. This is a reasonable assumption in the present context given the long list of types of works that can be potentially subject to censorship and the fact that countries might (and often do) have very different views regarding

66 Ibid., at 406.

67 Ibid., at 416, referring to Giovanni Maggi and Robert W. Staiger (2008), 'On the Role and Design of Dispute Settlement Procedures in International Trade Agreements', National Bureau of Economic Research Working Paper 14067. See Joel P. Trachtman (1999), 'The Domain of WTO Dispute Resolution', 40 Harvard International Law Journal, 333. 
censorship: what is deemed immoral or worthy of censorship is likely to vary across nations due to very different cultures, religions, and social norms regarding the freedom of expression. ${ }^{68}$

Under such circumstances, the exclusion from the trade agreement of disciplines on the degree of censorship would be optimal, providing governments with a high degree of discretion regarding its use. Indeed, Article 17 of the Berne Convention, incorporated by reference in the TRIPS, permits censorship without detailing any constraints on how and when it can be used.

\section{Nonviolation claims}

An alternative mechanism by which to address uncertainty and contracting costs is through a mechanism such as the remedy for nonviolation nullification or impairment developed in the GATT context. We may evaluate the utility of nonviolation nullification or impairment (NV) doctrine to complete the WTO contract in areas beyond tariff concessions. We note that WTO member states have determined that, for the time being, member states will not exercise the right to bring NV complaints in connection with TRIPS. ${ }^{69}$

As applied more specifically to the China-IP Rights case, the question is whether NV should apply to the obligation of intellectual property protection under TRIPS. If NV claims become available under TRIPS, would it be possible for the United States to make an NV claim against China, on the basis that China's censorship, authorized by Article 17 of the Berne Convention, nullifies or impairs US copyright rights under other provisions of TRIPS? Interestingly, in the Asbestos case, ${ }^{\mathbf{7 0}}$ the Appellate Body suggested that even where a state took advantage of a policy exception - Article XX of GATT - it might be required to compensate the complainant for nullification or impairment of the complainant's rights. Of course, in the context of the present case, the extent of Chinese censorship was well known prior to China's accession to the WTO, and so it would be difficult for the United States to argue formally that it had 'legitimate expectations' of a noncensorship state of affairs, as required by existing doctrine. But would the availability of a general NV claim in TRIPS otherwise be appropriate?

The case for extending TRIPS to include the possibility of NV claims would appear to be no weaker than that for the original inclusion of NV claims in Article XXIII in GATT. After all, the point of this article under GATT is to prevent the erosion of previously granted market access. The question posed by Bagwell and

68 Recall, for example, that Salman Rushdie's novel The Satanic Verses met with critical acclaim in the West but was considered offensive enough by Islamic fundamentalists to have earned him a fatwā from Ayatollah Khomeini of Iran in 1989. Indeed, the novel was even banned in India, a secular democracy with a large Muslim population.

69 Article 64.2 of TRIPS specified that NV would not be available with respect to TRIPS for the first five years from the date of entry into force of the WTO Agreement. Paragraph 45 of the 2005 Hong Kong Ministerial Declaration seems to have extended the period of nonapplication of NV indefinitely.

70 Appellate Body Report, European Communities-Measures Affecting Asbestos and AsbestosContaining Products (WT/DS135/AB/R, adopted 5 April 2001). 
Staiger is of immediate relevance here. ${ }^{71}$ They ask: to what extent must nations cede control over domestic policies (that only affect other countries in a pecuniary manner) in order to achieve economic efficiency in an interdependent world? While their analysis is motivated by the interaction between trade policies (such as tariffs) and domestic policies (such as labor and environmental standards), their findings have implications for the present context as well.

One could view the extent of censorship practiced by a country as a domestic standard that has no direct economic impact on its trading partners except for its effects on prices of copyrighted works (i.e., the terms of trade). If so, Bagwell and Staiger's analysis implies that tariff negotiations (analogous to negotiations over the degree of IPR protection in our context) would not be sufficient to achieve efficiency, since each government has an incentive to reclaim a portion of the market access granted under such negotiations via manipulating its domestic standard. In the present context, this result means that TRIPS negotiations regarding copyright protection (i.e., market access) could be undone by the strategic use of censorship.

Perhaps more importantly, Bagwell and Staiger go on to show that an NV complaint procedure (such as that provided for under GATT Article XXIII) that either requires compensation for the trade effects of domestic-policy changes or permits the complainant to withdraw an equivalent market concession of its own can play an important role in helping achieve global efficiency by ensuring that previously granted market-access commitments remain intact. As noted above, while the sovereign right to censor may trump market-access commitments made under TRIPS, the availability of an NV complaint can help ensure that governments do not use this right in an opportunistic manner.

\section{Conclusion}

International trade agreements are generally intended to cause states to internalize policy externalities. The policy externalities that arise from domestic decisions regarding intellectual property protection may deprive foreign intellectual property owners of the monopoly profits that they would otherwise derive from intellectual property protection. In connection with intellectual property protection, even a state that lacks 'traditional' market power on world markets may be able to impose terms-of-trade externalities on other states by reducing its protection of intellectual property below the global optimum. For this reason, and because of the international public-goods aspects of intellectual property, states have incentives to undersupply intellectual property protection. At least in part, TRIPS seems to be an attempt to reduce these policy externalities, since it basically requires all WTO members to adopt the same level of IPR protection as that which prevails in the

71 Kyle Bagwell and Robert W. Staiger (2001), 'Domestic Policies, National Sovereignty, and International Economic Institutions’, 116:2 The Quarterly Journal of Economics, 519-562. 
industrialized world. As noted earlier, the literature has shown that the global harmonization of IPRs is neither necessary nor sufficient to achieve efficiency, even though individual nations have an incentive to undersupply IPR protection.

All contracts, and all international treaties, are incomplete. This case involves some good examples of treaty incompleteness. Incompleteness can arise from circumstances of uncertainty regarding the possible tradeoffs, and the optimal balance, between different goals, including state autonomy in censorship on the one hand and internalizing policy externalities in intellectual property protection on the other. Following HMS, we analyze the possibility that it might be efficient to allow states broad discretion over censorship. Alternatively, in connection with the requirement for criminal penalties, incompleteness can arise from uncertainty regarding the particular industry structure that might be involved, and what would constitute production of 'commercial scale' for that industry.

We have also questioned the rationale for the limitation on the use of NV complaints in connection with the TRIPS, since NV complaints may be used to reduce the possibility that states will use discretion, such as that granted with respect to censorship, in a manner that is inconsistent with the rationale for that discretion so as to defect from the general commitment to provide copyright or other intellectual property rights. 